\title{
Enrichment of porcine spermatogonia by differential culture
}

\author{
E. Behboodi, S. Mohan, J.R. Rodriguez-Sosa, Y. Li, S. Megee and \\ I. Dobrinski*
}

Center for Animal Transgenesis and Germ Cell Research, School of Veterinary Medicine, University of Pennsylvania, Kennett Square, PA 19348, USA; * current address: Department of Comparative Biology \& Experimental Medicine, Faculty of Veterinary Medicine, University of Calgary, Calgary, Alberta T2N 4N1, Canada

Undifferentiated spermatogonia are a potential source of pluripotent cells and could be used for targeted genetic alteration in pigs. Our understanding of mechanisms maintaining porcine spermatogonial stem cells (SSCs) in vivo and of conditions to propagate SSCs in vitro remains limited. This is largely due to the small number of SSCs present in the testis and the lack of specific morphological and cell-surface markers to isolate a purified population. The goal of this study was to establish a modified differential culture system to effectively enrich SSCs from prepubertal porcine testes for subsequent culture.

Germ cell enrichment was quantified by immunocytochemistry and RT-PCR analysis of proteins and genes known to be specifically expressed in spermatogonia (PGP 9.5, VASA and DBA). Testes were collected from 10 week-old pigs and washed with PBS and transported on ice within $24 \mathrm{~h}$ to the laboratory in PBS that was supplemented with antibiotics. Testes were pooled for the isolation of germ cells (2-4 testes per trial). Cells were isolated by a two step enzymatic digestion (Honaramooz et al, 2002). The cells were incubated in DMEM containing $0.1 \mathrm{mM}$ 1-mercaptoethanol, $0.1 \mathrm{mM}$ MEM non-essential amino-acids, $200 \mathrm{mM} \mathrm{L-} \mathrm{Glutamine}$ and $5 \%$ FCS supplemented with $100 \mathrm{IU}$ penicillin streptomycin, in tissue culture dishes coated with $0.01 \%$ gelatin $12 \mathrm{~h}$ prior to use, at a concentration of $50 \times 10^{6}$ cells per dish $(60 \times 15 \mathrm{~mm})$ for $1 \mathrm{~h}$ at $37^{\circ} \mathrm{C}$ in $5 \% \mathrm{CO}_{2}$ in air. By counting cells in the supernatant it was determined that $50 \%$ of the total cells attached to the culture plates after $1 \mathrm{~h}$, most of which were somatic cells. Germ cells largely remained in suspension and were transferred to new culture dishes. After an additional $14 \mathrm{~h}$ of incubation, unattached cells were collected, concentrated by centrifugation for $5 \mathrm{~min}$ and counted before use for long term culture. Enrichment of germ cells at each time point $(0,14 \mathrm{~h})$ was determined by immunocytochemistry for alkaline phosphatase activity, and expression of DBA, PGP 9.5 and VASA. Counterstaining for vimentin was employed to identify somatic cells. mRNA was isolated for RT-PCR analysis to confirm expression of PGP 9.5 and VASA. Isolated cells were seeded at a density of $5 \times 10^{5}$ cells in 6-well plates in DMEM medium as above, supplemented with glial cell-derived neurotrophic factor (GDNF, $20 \mathrm{ng}$ / $\mathrm{ml}$ ), epidermal growth factor (EGF; $200 \mathrm{ng} / \mathrm{ml}$ ), and basic fibroblast growth factor (bFGF; 200 $\mathrm{ng} / \mathrm{ml}$ ). Comparison between groups was by Student's t-test.

The two-step differential culture increased the concentration of germ cells from $5.4 \pm 3 \%$ in the initial cell suspension to $46.6 \pm 22 \%$ in the non-adherent population at $14 \mathrm{~h}$ of culture (Table 1). Enriched germ cells formed more $(21 \pm 7$ versus $10 \pm 3.4 ; P<0.01)$ and larger colonies at day $7-10$ post culture than those arising from control cells not subjected to differential culture (Table 2).

The cultured cells grew vigorously in medium that was supplemented with growth factors as mentioned above. Cultured cells formed colonies by 5-6 days, which became compacted 
and formed three dimensional structures at day 8-10. When these colonies were removed physically and transferred to a new culture dish without feeder cells they differentiated to cells with fibroblast like morphology. These cells did not form three dimensional colonies and most cells stained negative for PGP 9.5 and VASA.

Table 1: Germ cell enrichment by differential culture

\begin{tabular}{cccc}
\hline Testis cells $($ Oh) & Germ cells & $\begin{array}{c}\text { Enriched testis cells } \\
(14 \mathrm{~h})\end{array}$ & Germ cells \\
\hline Cell no. $\left(\times 10^{6}\right)$ & $(\%)$ & Cell no. $\left(\times 10^{6}\right)$ & $(\%)$ \\
290 & 8.2 & 12 & 74.0 \\
300 & 5.3 & 13 & 41.3 \\
300 & 4.1 & 8 & 62.5 \\
300 & 5.3 & 6 & 35.0 \\
200 & 4.0 & 6 & 17.5 \\
$278 \pm 44$ & $5.4 \pm 1.7$ & $5.4 \pm 3.3$ & $46 \pm 22$ \\
\hline
\end{tabular}

Table 2: Colony formation after 7-10 days in vitro

\begin{tabular}{|c|c|c|c|}
\hline $\begin{array}{l}\text { Replicates per experiment } \\
(0 \mathrm{~h})\end{array}$ & $\begin{array}{l}\text { Colony No. per dish } \\
\text { (Oh) }\end{array}$ & $\begin{array}{l}\text { Replicates per } \\
\text { experiment (14h) }\end{array}$ & Colony No. per dish (14h) \\
\hline 2 & 6 & 2 & 11 \\
\hline 2 & 12 & 2 & 30 \\
\hline 2 & 15 & 2 & 25 \\
\hline 2 & 12 & 2 & 19 \\
\hline \multirow[t]{2}{*}{2} & 9 & 2 & 22 \\
\hline & $10 \pm 3.4$ & & $21 \pm 7.0$ \\
\hline
\end{tabular}

Oh: Cells plated without enrichment

$14 \mathrm{~h}$ : Cells plated after enrichment

Student's T-test $\mathrm{P}<0.01$

These results indicate that the two-step differential culture protocol results in a 10 -fold enrichment of germ cells from prepubertal porcine testis. Propagation of germ cell colonies in cells maintained in vitro for 7-10 days requires the presence of feeder cells. Enriched germ cell populations can now be used more efficiently for further expansion and genetic modification of porcine germ cells in vitro.

This study was, supported by grant \# 2-R01RR017359-06 from the NIHINCRR

\section{Reference}

Honaramooz A, Megee SO \& Dobrinski 12002 Germ cell transplantation in pigs. Biology of Reproduction 66 21-28. 